\title{
A Novel Anti-B7-H3 $\times$ Anti-CD3 Bispecific Antibody with Potent Antitumor Activity
}

\author{
Yan Feng ${ }^{1}$, Kun Xie ${ }^{1}$, Yanxin Yin ${ }^{1,2}$, Bingyu Li ${ }^{1}$, Chenyu Pi ${ }^{1}$, Xiaoqing Xu ${ }^{1} \mathbb{1}$, Tao Huang ${ }^{1}$, Jingming Zhang ${ }^{1}$, \\ Bo Wang ${ }^{1}$, Hua Gu ${ }^{1, *}$ and Jianmin Fang ${ }^{1,2,3, *}$
}

1 School of Life Sciences and Technology, Tongji University, Shanghai 200092, China; fengyango12@163.com (Y.F.); kunxiebio@126.com (K.X.); yyx0301mu@126.com (Y.Y.); libingyu006@163.com (B.L.); 15221536768@163.com (C.P.); xuxiao_qing01@163.com (X.X.); huangtao@tongji.edu.cn (T.H.); zjm2020pro@outlook.com (J.Z.); wangbo15619@163.com (B.W.)

2 Biomedical Research Center, Suzhou 230031, China

3 Shanghai Tongii Hospital, Shanghai 200065, China

* $\quad$ Correspondence: gu_hua@tongji.edu.cn (H.G.); jfang@tongji.edu.cn (J.F.); Tel.: +86-021-65982878 (H.G. \& J.F.)

Citation: Feng, Y.; Xie, K.; Yin, Y.; Li, B.; Pi, C.; Xu, X.; Huang, T.; Zhang, J.; Wang, B.; Gu, H.; et al. A Novel Anti-B7-H3 $\times$ Anti-CD3 Bispecific Antibody with Potent Antitumor Activity. Life 2022, 12, 157. https://doi.org/10.3390/ life12020157

Academic Editor: Sergey Sedyh

Received: 19 December 2021

Accepted: 15 January 2022

Published: 21 January 2022

Publisher's Note: MDPI stays neutral with regard to jurisdictional claims in published maps and institutional affiliations.

Copyright: (C) 2022 by the authors. Licensee MDPI, Basel, Switzerland. This article is an open access article distributed under the terms and conditions of the Creative Commons Attribution (CC BY) license (https:// creativecommons.org/licenses/by/ $4.0 /)$.

\begin{abstract}
B7-H3 plays an important role in tumor apoptosis, proliferation, adhesion, angiogenesis, invasion, migration, and evasion of immune surveillance. It is overexpressed in various human solid tumor tissues. In patients, B7-H3 overexpression correlates with advanced stages, poor clinical outcomes, and resistance to therapy. The roles of B7-H3 in tumor progression make it a potential candidate for targeted therapy. Here, we generated a mouse anti-human B7-H3 antibody and demonstrated its binding activity via Tongji University Suzhou Instituteprotein-based and cell-based assays. We then developed a novel format anti-B7-H3 $\times$ anti-CD3 bispecific antibody based on the antibody-binding fragment of the anti-B7-H3 antibody and single-chain variable fragment structure of anti-CD3 antibody (OKT3) and demonstrated that this bispecific antibody mediated potent cytotoxic activities against various B7-H3-positive tumor cell lines in vitro by improving $\mathrm{T}$ cell activation and proliferation. This bispecific antibody also demonstrated potent antitumor activity in humanized mice xenograft models. These results revealed that the novel anti-B7-H3 $\times$ anti-CD3 bispecific antibody has the potential to be employed in treatment of B7-H3-positive solid tumors.
\end{abstract}

Keywords: B7-H3; bispecific T cell engager; solid tumor; immunotherapy

\section{Introduction}

Over the past few years, the number of reports demonstrating the development and effects of therapeutic bispecific antibodies (bsAbs) has increased rapidly. Currently, various bsAbs for cancer therapy are under clinical development, and bispecific $\mathrm{T}$ cell engager (bsTCEs) represent the largest group. The strategy involving redirection of effector T cells to kill target cells demonstrate significant potential in cancer immunotherapy $[1,2]$. bsTCEs have shown potent therapeutic effects in treatment of hematologic malignancies but the benefit in treatment of solid tumors has been far less promising. The treatment of solid tumors is difficult owing to several factors such as antigen expression in critical normal tissues, immunosuppressive tumor microenvironment, disordered tumor vasculature, and less effector cells infiltration in tumor tissues. One of the hurdles is selection of a tumor-associated antigen (TAA) specifically targeting solid tumor, as expression on critical normal tissues of solid tumor TAA can lead to adverse events by on-target off-tumor T cell reactivity [3].

B7-H3 (CD276), a B7 superfamily member, was identified as a T cell co-stimulatory and co-inhibitory molecule. B7-H3 demonstrates positive regulatory functions in cytotoxic $\mathrm{T}$ cell proliferation, activation, and IFN- $\gamma$ production in vitro [4]. Other studies have also shown the co-stimulatory role of $\mathrm{B} 7-\mathrm{H} 3$, which is seemingly correlated with enhanced therapy efficacy and prolonged survival [5-8]. However, most subsequent studies have 
demonstrated that B7-H3 is involved in T cell inhibition and is emerging as an important regulator of tumor progression [9-13]. B7-H3 also participates in tumor progression via a non-immunological reaction. High B7-H3 expression has been detected in multiple human solid tumor tissues such as non-small cell lung cancer [14], prostate cancer [15-17], pancreatic cancer [8,18], ovarian carcinoma [19], endometrial carcinoma [20], colorectal cancer [21], hepatocellular carcinoma [22], breast cancer [23], clear cell renal cell cancer [24], and head and neck cancer [25]. Besides its overexpression on tumor cells, B7-H3 is overexpressed on tumor-infiltrating dendritic cells, macrophages, monocytes, tumor-associated fibroblasts, endothelial cells, and cancer stem cells [19,24-27]. B7-H3 overexpression in tumor tissues correlates with decreased $\mathrm{T}$ cell infiltration, poor prognosis, increased metastasis, advanced clinical stage, and resistance to therapy [15,24-27]. Furthermore, B7-H3 expression is limited at low levels in healthy tissues [28].

Collectively, B7-H3 is a potential target for solid tumor treatment. Many therapy approaches targeting $\mathrm{B} 7-\mathrm{H} 3$, including monoclonal antibody $(\mathrm{mAb})$, chimeric antigen receptor $\mathrm{T}$ cells (CAR-T), antibody-drug conjugate (ADC), and bsAb are undergoing evaluation in preclinical and clinical trials and have shown impressive therapeutic efficacy [28-33]. Although some bsTCEs targeting B7-H3 also have shown anti-tumor effects in preclinical studies, until now, only MGD009 has been studied in clinical studies. MGD009, also known as Orlotamab, is a humanized, Fc-bearing dual affinity re-targeting (DART) format molecule that recognizes B7-H3 and CD3. Treatment with MGD009 in tumor-engrafted mice showed recruitment of $\mathrm{T}$ cells to the tumor site and dose-dependent antitumor activity [34]. MGD009 has been studied in two clinical studies (NCT02628535, NCT03406949). Except for MGD009, most of these anti-B7-H3 bsTCEs were synthesized by linking the anti-CD3 antibody and anti-B7-H3 antibody using chemical coupling agents; thus, the size of these antibodies is large, which may negatively affect physicochemical properties such as solubility [35-38]. Some other anti-B7-H3 bsTCEs are designed as a bispecific T cell engager (BiTE) format with short half-life $[39,40]$. More anti-B7-H3 bsTCEs with different structures may should be pursued for B7-H3 targeting therapy.

In this study, we aimed to develop a novel format asymmetric anti-B7-H3 $\times$ anti-CD3 bispecific antibody ( $\alpha$ B7-H3/CD3) based on antibody-binding fragment (Fab) of anti-B7-H3 $\mathrm{mAb}$ and single chain variable fragment $(\mathrm{scFv})$ of anti-CD3 mAb (OKT3) and examine its binding activity, cytotoxic potential, and underlying mechanisms against tumor cell lines. The results demonstrated that the bsAb were able to significantly induce activation and proliferation of $\mathrm{T}$ cells and mediate tumor cell lysis. Furthermore, we evaluated the in vivo tumor inhibition activity of the bsAb in xenograft models of glioblatoma and ovarian carcinoma using an NCG humanized mice model. The tumors regressed and were completely eliminated upon treatment with $\alpha \mathrm{B} 7-\mathrm{H} 3 / \mathrm{CD} 3$.

\section{Materials and Methods}

Unless stated, experiments were performed according to manufacturer's protocol.

\subsection{Cell Lines}

FreeStyle $^{\mathrm{TM}}$ 293T cells were obtained from Thermo Fisher Scientific (Gibco, Carlsbad, CA, USA) and cultured in FreeStyle ${ }^{\mathrm{TM}} 293$ medium (12338018, Gibco, Carlsbad, CA, USA) at $37^{\circ} \mathrm{C}, 8 \% \mathrm{CO}_{2}$, and $120 \mathrm{rpm}$. Human tumor cells A498, SKOV3, MDA-MB-468, A549, HepG2, BCPAP, and Raji were obtained from ATCC (Rockville, MD, USA) and stored in our lab. U-87 MG, PANC-1, MDA-MB-231, AsPC-1, and K562 were obtained from NCACC (Shanghai, China) and stored in our lab. Cells were maintained at $37{ }^{\circ} \mathrm{C}$ and $5 \% \mathrm{CO}_{2} . \mathrm{A} 498$, U-87 MG, SKOV3, MDA-MB-468, PANC-1, A549, BCPAP, MDA-MB-231, HepG2, and AsPC1 were cultured in DMEM (Hyclone, Waltham, MA, USA) supplemented with $100 \mathrm{U} / \mathrm{mL}$ penicillin, $100 \mu \mathrm{g} / \mathrm{mL}$ streptomycin (Gibco, Carlsbad, CA, USA), and 10\% fetal bovine serum (FBS) (Cegrogen, Stadtallendorf, Germany). K562, and Raji were maintained in RPMI 1640 (Hyclone, Waltham, MA, USA) with $100 \mathrm{U} / \mathrm{mL}$ penicillin, $100 \mu \mathrm{g} / \mathrm{mL}$ streptomycin, and $10 \%$ FBS. 


\subsection{Production of Anti-B7-H3 $m A$ ss and Bispecific Antibody}

Bivalent anti-B7-H3 antibodies were produced using the hybridoma method. BALB/c mice were immunized with recombinant extracellular domain of human B7-H3 linked to His tag protein (B7-H3-ECD) (11188-H08H, SinoBiological, Beijing, China). Parental mAb against B7-H3 were screened based on the results of the protein and cell binding using ELISA and flow cytometry, respectively. The chimeric mAb (10-2\#c) was generated by fusing the anti-B7-H3 antibody variable light chain (VL) to the human IgG1 light chain constant region $(\mathrm{CK})$ and the anti-B7-H3 antibody variable heavy chain $(\mathrm{VH})$ to the human IgG1 heavy chain constant region $(C \gamma 1)$.

The $\alpha \mathrm{B} 7-\mathrm{H} 3 / \mathrm{CD} 3$ format was developed based on the heterodimeric $\mathrm{F}_{\mathrm{C}}$ variant via the knobs-into-holes technique (KIH) [41,42]. The mutations T366S, L368A, and Y407V were introduced into $\mathrm{CH} 3$ domain of heavy chain hole-Fc and mutation T366W was introduced into $\mathrm{CH} 3$ domain of a single knob-Fc chain. Both Fc parts carried the N297A mutation to abolish Fc-mediated effector functions [43,44]. The light chain was constructed with an anti-CD3 scFv (huOKT3, GenBank: AND42858.1) fused to 10-2\#c light chain C-terminus by a 15-amino acid linker $\left(\mathrm{G}_{4} \mathrm{~S}\right)_{3}$.

\subsection{Expression and Purification of Antibodies}

DNA fragments encoding heavy and light chains were synthesized by Genewiz (Azenta Life Sciences, Suzhou, China) and cloned into the pcDNA3.1+ vector. To express antibodies, three vectors were co-transfected into FreeStyle ${ }^{\mathrm{TM}}$ 293T cells for transient expression, and supernatants were collected 7 days post-transfection. Antibodies were purified using Protein A affinity chromatography (Thermo Fisher Scientific Co., Ltd.) and then further purified using anti-flag affinity column (Flag tag was fused to $C$ terminus of knob Fc fragment) (P2271, Beyotime, Shanghai, China). Protein samples were analyzed using SDS electrophoresis.

\subsection{Preparation of Primary Cells}

PBMCs were isolated using Ficoll-Hypaque density gradient centrifugation (Tbdscience, Tianjin, China) from healthy donors and cultured in IMDM (Hyclone, Waltham, MA, USA) supplemented with $100 \mathrm{U} / \mathrm{mL}$ penicillin, $100 \mathrm{U} / \mathrm{mL}$ streptomycin, and $10 \%$ heatinactivated FBS [45]. Human CD3+ T cells were isolated using a negative selection human CD3 T cell isolation kit (480022, BioLegend, San Diego, CA, USA). The pre-selection and post-selection (positive and negative fractions) purities were tested using flow cytometry.

\subsection{Cell Binding Assay}

Tumor cell lines, PBMCs, and CD3+ T cells were separately incubated with serially diluted indicated concentrations (0.0001-100 $\mu \mathrm{g} / \mathrm{mL}$ ) of anti-B7-H3 mAb (10-2\#c) or $\alpha$ B7H3/CD3 for $1 \mathrm{~h}$ on ice and stained with APC-anti-human IgG (409306, BioLegend, San Diego, CA, USA) in the dark for $30 \mathrm{~min}$. Cell binding activity was analyzed using flow cytometry (CytoFLEX LX, Beckman Coulter, Brea, CA, USA).

\subsection{In Vitro Cytotoxicity Assay}

Target cells $\left(5 \times 10^{3}-1 \times 10^{4}\right)$ labeled with $2 \mu$ M calcein-AM (425201, BioLegend, San Diego, CA, USA) were co-cultured with effector cells and the indicated concentrations (0.00001-1000 ng/mL) of $\alpha$ B7-H3/CD3 or other antibodies (anti-CD3 mAb (317325, Biolegend, San Diego, CA, USA) or anti-B7-H3 mAb (10-2\#c) or mixture) for $12-24 \mathrm{~h}$ at $37^{\circ} \mathrm{C}$ [46]. PBMCs or CD3+ T cells from healthy donors were used as effector cells, and the effector-totarget (E:T) ratio was 10:1. After co-culture, cells were harvested and analyzed using flow cytometry. Calcein-AM+ cells were evaluated as live target cells, and the group without antibodies was analyzed as the control. Cell death X (\%) was calculated as (1-percentage of live cells in X group/percentage of live cells in control group) $\times 100$. 


\subsection{T Cell Activation Assay and Cytokine Release Assay}

For the $\mathrm{T}$ cell activation assay, CD3+ T cells or PBMCs were co-cultured with tumor cells and $1 \mu \mathrm{g} / \mathrm{mL}$ of $\alpha \mathrm{B} 7-\mathrm{H} 3 / \mathrm{CD} 3$ or other antibodies (anti-CD3 mAb or anti-B7-H3 mAb or mixture) for $24 \mathrm{~h}$ in 96-well culture plates (E:T = 10:1). After that, cells were collected and stained with detection antibodies. Part of cells were stained with APC-anti-human CD4 (357408, BioLegend, San Diego, CA, USA), PC5.5-anti-human CD8 (344710, BioLegend, San Diego, CA, USA), and PE-anti-human CD69 (310906, BioLegend, San Diego, CA, USA) for $30 \mathrm{~min}$ in the dark. Another portion was stained with APC-anti-human CD4 (357408, BioLegend, San Diego, CA, USA) and PC5.5-anti-human CD8 (344710, BioLegend, San Diego, CA, USA), and then fixed and permeabilized prior to staining with PE-antihuman/mouse granule granzyme B (GrB) (372208, BioLegend, San Diego, CA, USA). T cell activation was determined by flow cytometry. Supernatants were collected to quantify the release of interleukin 2 (IL-2) (431804, BioLegend, San Diego, CA, USA), interleukin 6 (IL-6) (430504, BioLegend, San Diego, CA, USA), and IFN- $\gamma$ (430104, BioLegend, San Diego, CA, USA) after cell culture for $48 \mathrm{~h}$ using ELISA kits.

\subsection{T Cell Proliferation Assay}

CFSE were used for T cell proliferation measurement [47]. U-87 MG cells $\left(1 \times 10^{4}\right)$ were incubated with CFSE (423801, BioLegend, San Diego, CA, USA)-labeled purified human $\mathrm{CD} 3+\mathrm{T}$ cells supplemented with $1 \mu \mathrm{g} / \mathrm{ml} \alpha \mathrm{B} 7-\mathrm{H} 3 / \mathrm{CD} 3$ or other antibodies (anti-CD3 $\mathrm{mAb}$ and anti-B7-H3 mAb or mixture) for 5 days in 96-well plates $(\mathrm{E}: \mathrm{T}=10: 1)$. Cells were collected and stained with APC-anti-human CD4 and PC5.5-anti-human CD8 antibodies. CFSE dilution was analyzed using flow cytometry.

\subsection{Ethics Statement}

NCG mice (GemPharmatech, Nanjing, China) were maintained in pathogen-free conditions. All procedures were performed under the guidelines of Directive 2010/63/EU from the European Union. The protocol was approved by the Animal Research Ethics Committee of Tongji University (No. TJLAC-018-032). Informed consent was obtained from the PBMCs donors.

\subsection{In Vivo Xenograft Model}

NCG mice (6-8 weeks old) were intravenously (i.v.) inoculated with $8 \times 10^{6}$ huPBMCs via the tail vein approximately 2 weeks before $5 \times 10^{6} \mathrm{U}-87 \mathrm{MG} / \mathrm{SKOV} 3$ cells were subcutaneously (s.c.) transplanted into mice [48]. When tumor volume was about $150 \mathrm{~mm}^{3}$, U-87 MG xenograft bearing mice were randomized into six groups (no PBMC, PBS, $\alpha$ B7$\mathrm{H} 3 / \mathrm{CD} 3(0.2,1$, and $5 \mathrm{mg} / \mathrm{kg}$ ) and anti-B7-H3 mAb 10-2\#c (5 mg/kg)). SKOV3 xenograft bearing mice were randomized into four groups (no PBMC, PBS, and $\alpha B 7-\mathrm{H} 3 / \mathrm{CD} 3(0.2$ and $1 \mathrm{mg} / \mathrm{kg}$ )). Drugs were intraperitoneally (i.p.) injected twice per week. The bodyweight of mice and length $(\mathrm{mm})$ and width $(\mathrm{mm})$ of tumors were monitored every 2 or 3 days. Tumor volume $\left(\mathrm{mm}^{3}\right)$ was calculated as Length $\times$ Width $^{2} \times 1 / 2$. When the average tumor volume exceeded $1500 \mathrm{~mm}^{3}$, mice were euthanized.

\subsection{Immunofluorescence Staining}

Murine tumor tissues sections were fixed in $4 \%$ paraformaldehyde for $20 \mathrm{~min}$ at $20{ }^{\circ} \mathrm{C}$ and blocked for $10 \mathrm{~min}$. Sections were then stained with anti-CD3 antibody (GB111337, Servicebio, Wuhan, China) overnight at $4{ }^{\circ} \mathrm{C}, \mathrm{Cy} 3$ conjugated secondary antibody (GB21303, Servicebio, Wuhan, China) for $1 \mathrm{~h}$, and DAPI (G1012, Servicebio, Wuhan, China) for $15 \mathrm{~min}$ in the dark. Images were captured with a fluorescence microscope.

\subsection{Statistical Analysis}

Statistical analyses were performed by GraphPad Prism 7.0. Statistical significance between groups was calculated using an unpaired two-tailed $t$-test or two-way/one-way anal- 
ysis of variance (ANOVA). For all figures, NS, non-significant; ${ }^{* * * *} p<0.0001 ;{ }^{* * *} p<0.001$; ${ }^{* *} p<0.01 ;{ }^{*} p<0.05$. Data are shown as means \pm SD.

\section{Results}

\subsection{Analysis of B7-H3 Expression and Generation of Anti-B7-H3 Antibody}

$\mathrm{B} 7-\mathrm{H} 3$ is highly expressed in various human carcinomas. To analyze B7-H3 expression on cell lines surface, we characterized human tumor cell lines from different tumor systems using flow cytometry. As shown in Figure 1a-1, most of the solid tumor cell lines showed a high expression of B7-H3 (A498, U-87 MG, SKOV3, A549, BCPAP, and MDA-MB-231); however, the hematoma tumor cell lines (K562 and Raji) showed low B7-H3 expression. On the surface of Raji cells, B7-H3 expression is almost negative.
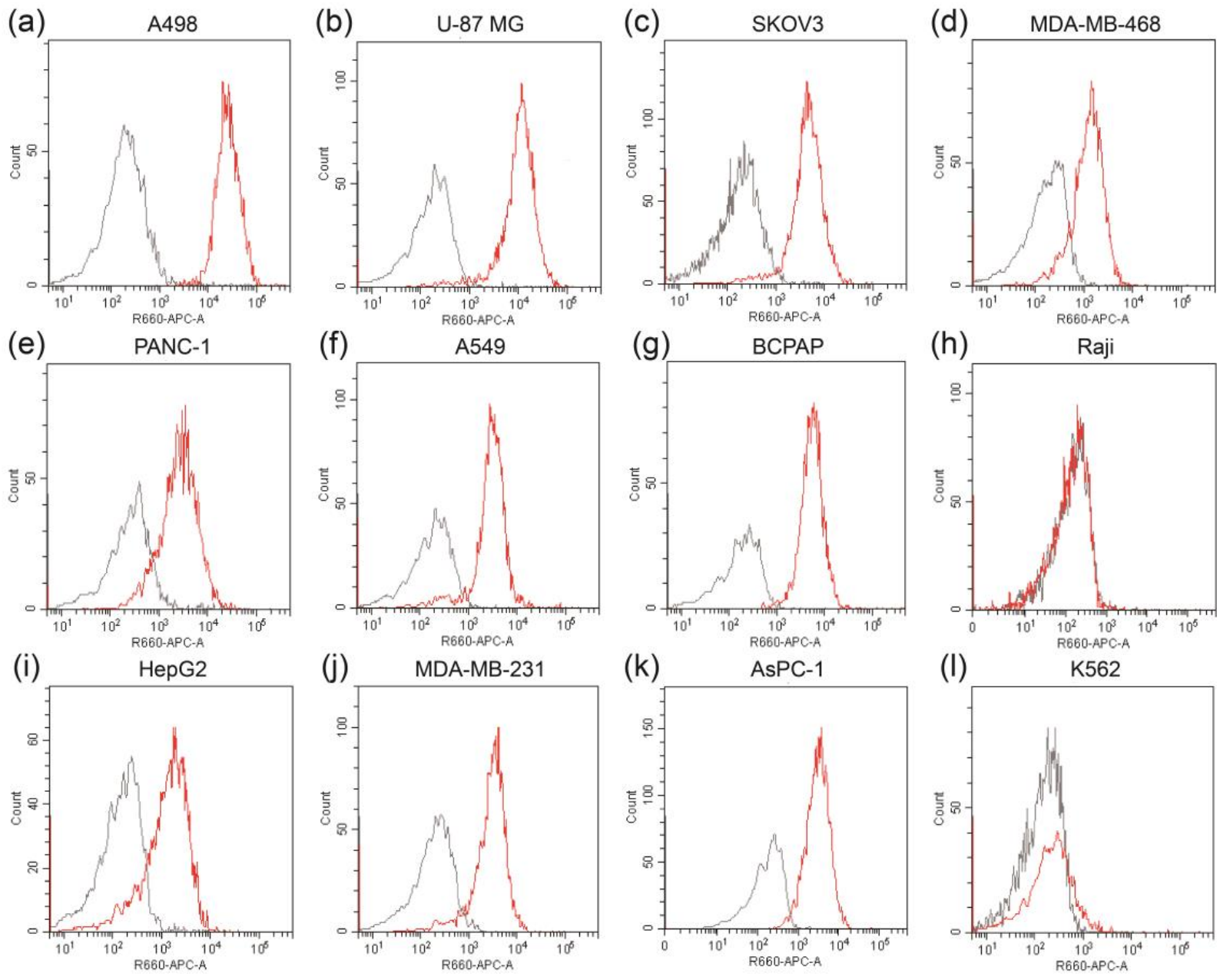

\section{CD276-APC}

Figure 1. B7-H3 is highly expressed on human solid tumor cell lines. (a-1) Expression of B7-H3 on cell lines (A498, U-87 MG, SKOV3, MDA-MB-468, PANC-1, A549, BCPAP, Raji, HepG2, MDA-MB-231, AsPC-1, and K562) was detected by flow cytometry. Gray histogram, isotype control; red histogram, APC-conjugated anti-human CD276 $(10 \mu \mathrm{g} / \mathrm{mL})$. MFI values (control/anti-human CD276) of these cell lines were, respectively, 160/25,090, 62/10,733, 62/4317, 57/1240, 134/2472, 67/2918, 60/3315, $4.5 / 15,71 / 1262,63 / 2966,60 / 2911$, and 26/84. MFI, median fluorescence intensity.

To study B7-H3-targeting therapy, we generated anti-B7-H3 monoclonal antibodies by immunizing BALB/c mice with B7-H3 ECD-His and selected antibody 10-2\# as the candidate for further studies based on the results of the binding assay. We then generated the chimeric antibody $10-2 \# \mathrm{c}$ by fusing $10-2 \# \mathrm{VL}$ to human $\mathrm{C} \kappa$ and $10-2 \# \mathrm{VH}$ to human $\mathrm{C} \gamma 1$. 
The 10-2\#c bound to human B7-H3-ECD protein with a half-maximal effective concentration $\left(E_{50}\right)$ value of $2.216 \mathrm{ng} / \mathrm{ml}$ (Figure $2 \mathrm{a}$ ). The antibody showed high binding activity to tumor cells showing high expression of B7-H3 (Figure $2 b-\mathrm{i}$ ).
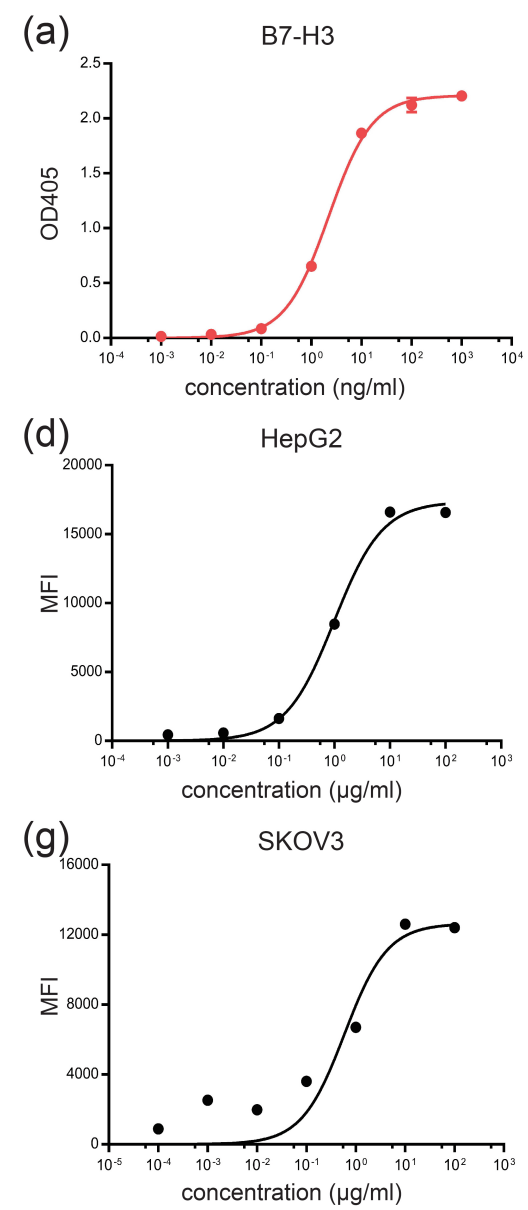

(b)

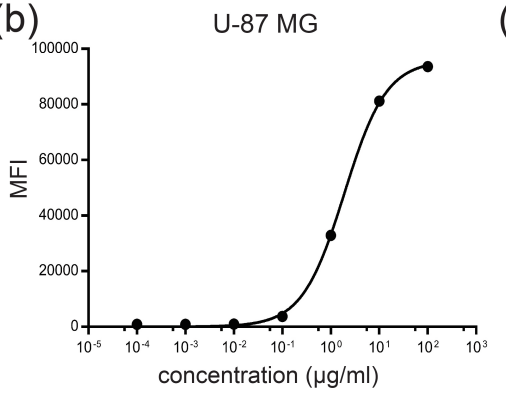

(e)

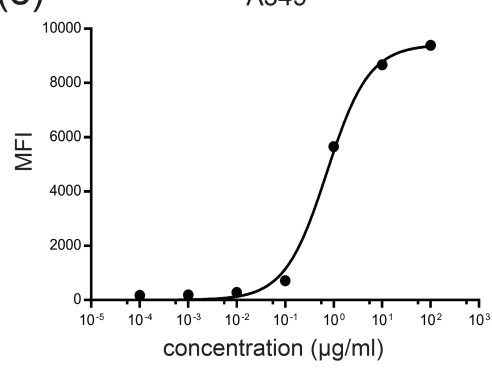

(h)

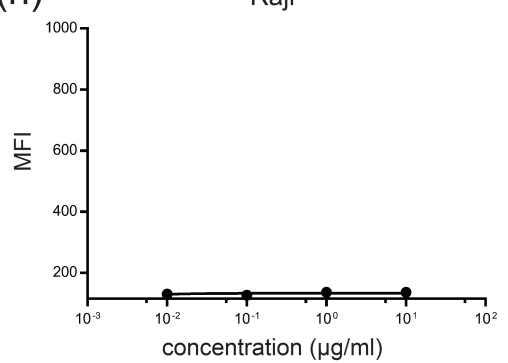

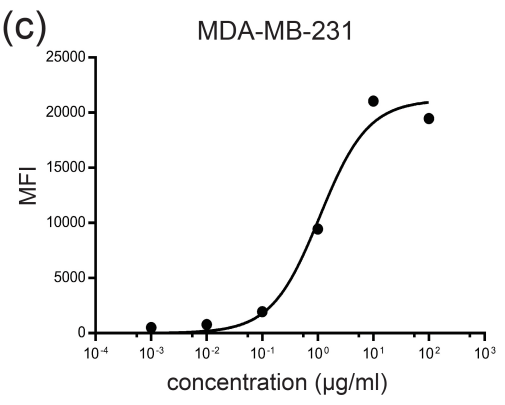

(f)

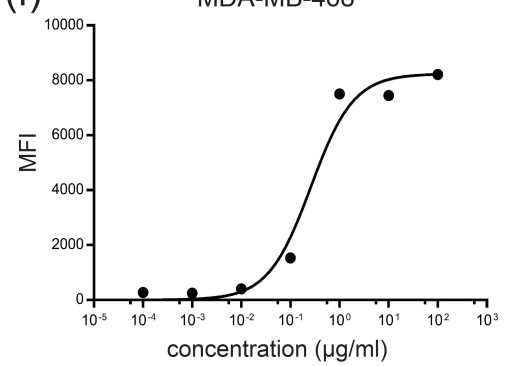

(i)

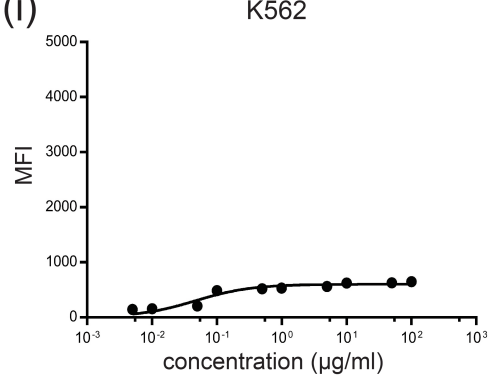

Figure 2. Anti-B7-H3 antibody 10-2\#c shows high binding activity to B7-H3 and cell lines with high B7-H3 expression. (a) The binding of 10-2\#c to human B7-H3 reconstituted protein was evaluated by ELISA $(n=3), \mathrm{EC}_{50}=2.216 \mathrm{ng} / \mathrm{ml} ;(\mathbf{b}-\mathbf{i})$ The binding of 10-2\# to cell lines (U-87 MG, MDA-MB-231, HepG2, A549, MDA-MB-468, SKOV3, Raji, and K562) was detected by flow cytometry. MFI, median fluorescence intensity. MFI values (control/maximum concentration of 10-2\#c) of these cell lines were, respectively, 834/93,630, 366/19,477, 353/16,980, 144/9385, 245/8215, 250/12,400, 125/136, and 140/646.

\subsection{Generation and Characterization of $\alpha B 7-H 3 / C D 3$}

To develop a bsAb for B7-H3-targeting, we constructed a bsTCE by linking scFv of anti-CD3 mAb (OKT3) to C-terminus of monovalent, single-arm anti-B7-H3 mAb light chain (Figure 3a). Purity and correct molecular weights of $\alpha$ B7-H3/CD3 were detected by non-reduced SDS-PAGE, and reduced SDS-PAGE showed three bands of $\alpha B 7-H 3 / C D 3$ : a $55 \mathrm{kDa}$ light chain, a $57 \mathrm{kDa}$ hole chain, and a $28 \mathrm{kDa}$ knob chain (Figure 3b). Flow cytometry revealed the high binding activity of $\alpha \mathrm{B} 7-\mathrm{H} 3 / \mathrm{CD} 3$ to cell lines showing high expression of B7-H3 (U-87 MG, A498, SKOV3, and MDA-MB-231) but not to cell lines showing low expression of B7-H3 (K562 and Raji) (Figure 3c-i). The antibody could dose-dependently bind to human CD3+ T cells (Figure 3j-k). Therefore, $\alpha \mathrm{B} 7-\mathrm{H} 3 / \mathrm{CD} 3$ demonstrated the ability to bind specifically to both B7-H3 and CD3 on the cell surface. 
(a)

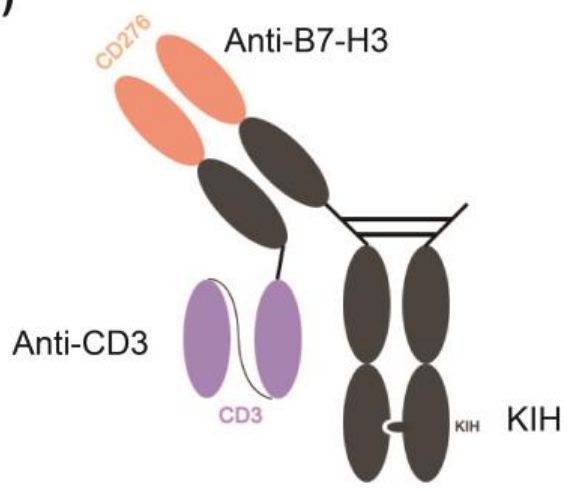

(b)

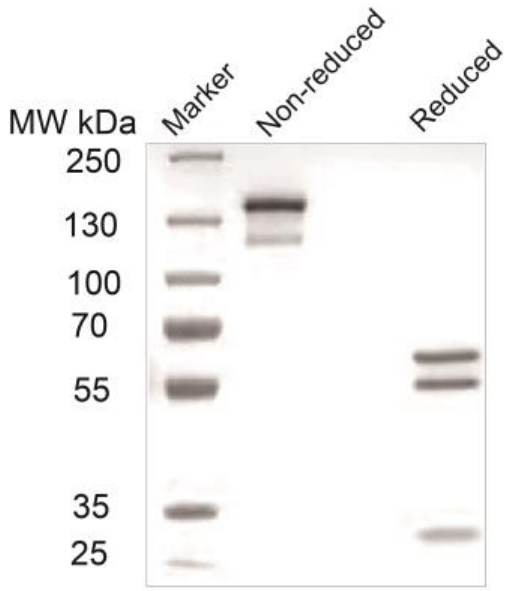

(e)

(d)
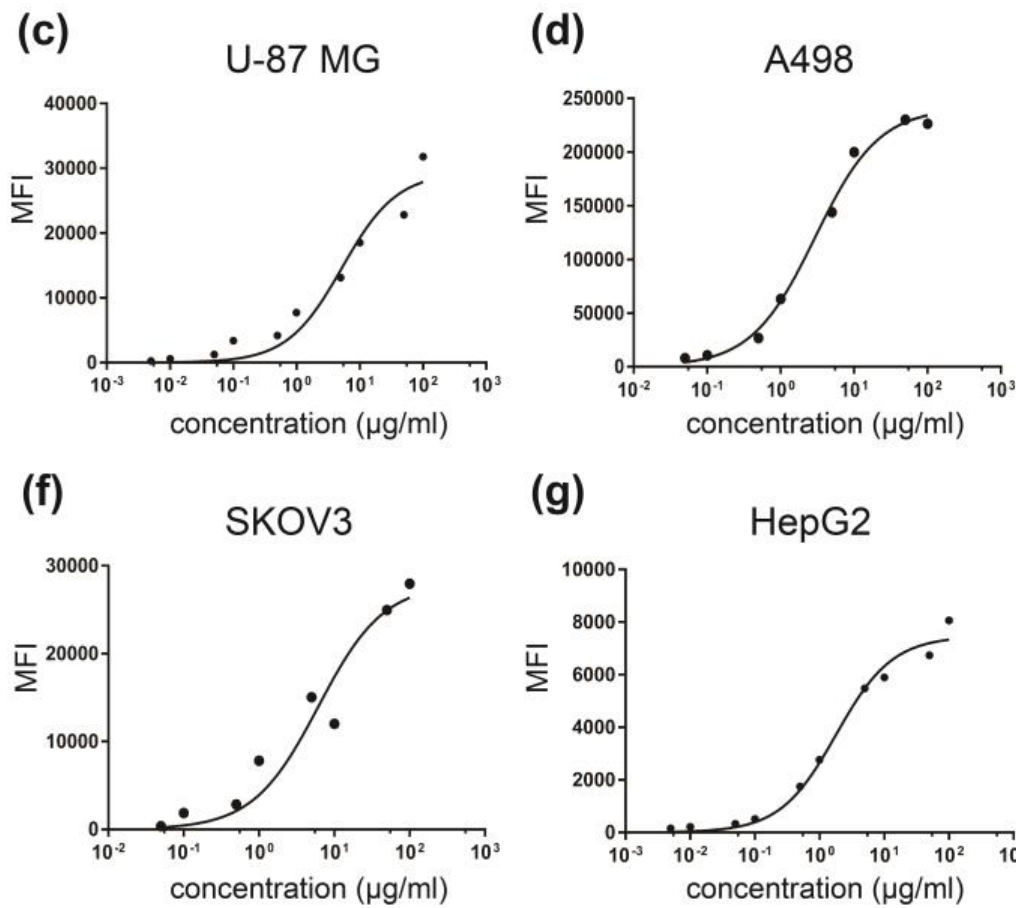

(i)

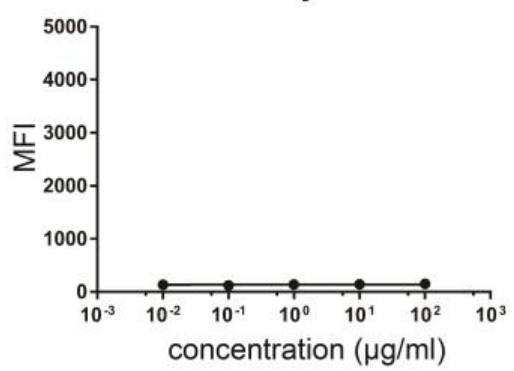

(g)

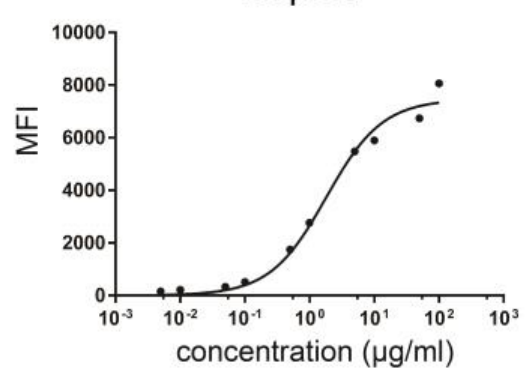

(j)

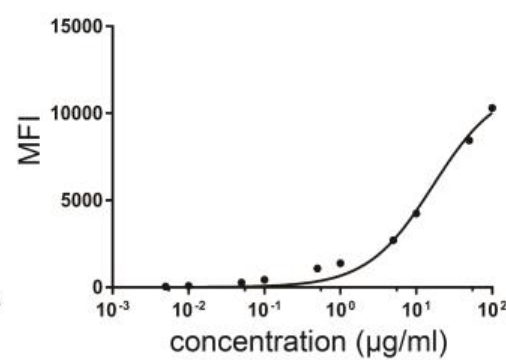

MDA-MB-231

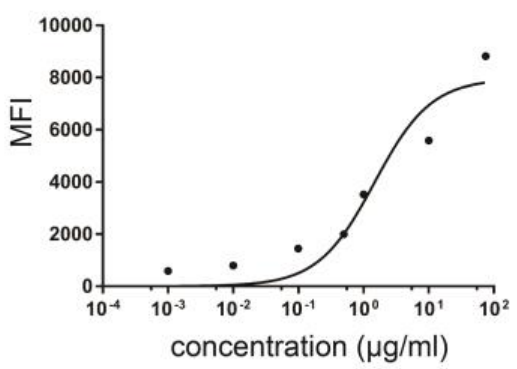

(h)

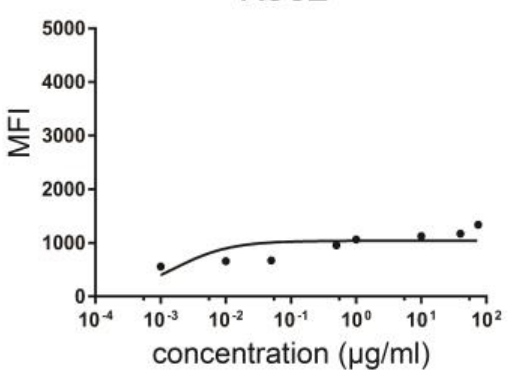

(k)

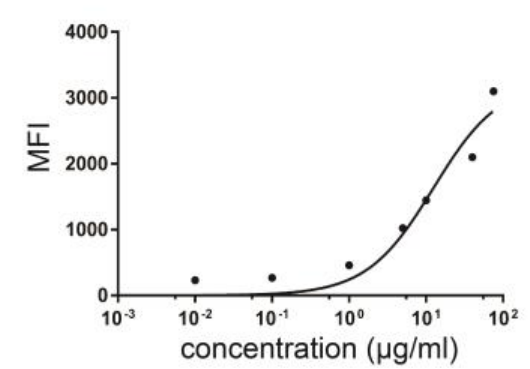

Figure 3. Generation and characterization of $\alpha \mathrm{B} 7-\mathrm{H} 3 / \mathrm{CD} 3$ bispecific antibody. (a) An illustrative representation of the $\alpha \mathrm{B} 7-\mathrm{H} 3 / \mathrm{CD} 3$ format. The format comprised an anti-CD3 scFv fused to light chain of a monovalent anti B7-H3 via a $\left(\mathrm{G}_{4} \mathrm{~S}\right)_{3}$ linker; (b) Coomassie blue-stained SDS-PAGE analysis of purified $\alpha \mathrm{B} 7-\mathrm{H} 3 / \mathrm{CD} 3$ containing three chains with the following molecular weights: 57,55 , and $28 \mathrm{kDa}$; (c-k) $\alpha \mathrm{B} 7-\mathrm{H} 3 / \mathrm{CD} 3$ bispecific antibody dose-dependently binds to B7-H3+ tumor cells and CD3+ T cells, evaluated using flow cytometry. MFI values (control/maximum concentration of 10 $2 \# c)$ of these cell lines were, respectively, 205/31,800, 7500/226,444, 480/5700, 350/27,950, 150/8065, $480 / 1550,125 / 155,50 / 10,300$, and 195/3100. 


\section{3. $\alpha B 7-H 3 / C D 3$ Mediates T Cell Cytotoxicity against B7-H3-Overexpressing Cells In Vitro}

We then evaluated whether engagement of B7-H3 high expression cells and T cells mediated by $\alpha$ B7-H3/CD3 can trigger tumor cell lysis. The potency of cytotoxic effects was first assessed against the B7-H3-high expression cell line U-87 MG. Results showed remarkable $\alpha$ B7-H3/CD3-mediated T cell cytotoxicity against U-87 MG cells, and U-87 MG cells were lysed in dose-dependent manner (Figure 4a,b). The anti-B7-H3 or/and anti-CD3 $\mathrm{mAb}$ could mediate the cytotoxicity activity leading to tumor cell death, but the effect was limited (Figure 4a).

(a)

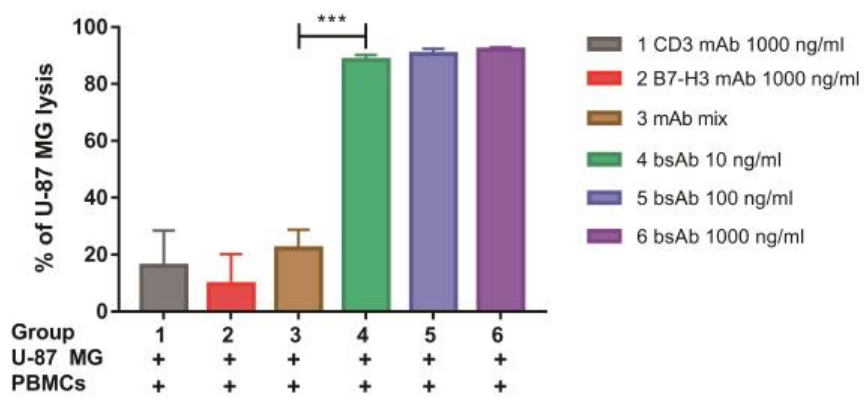

(c)

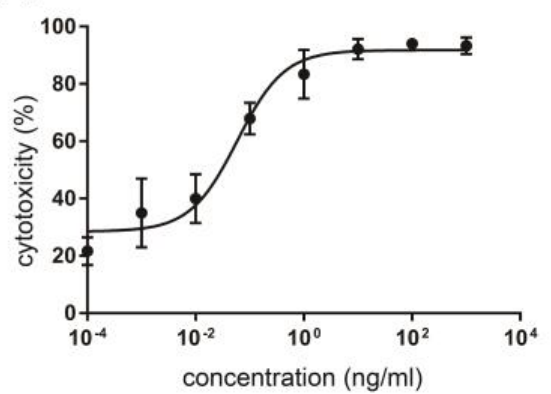

(f)

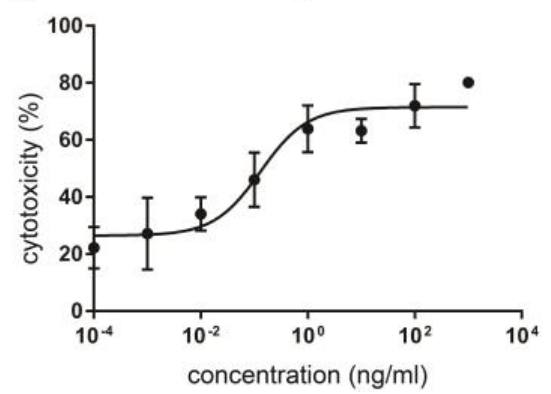

(d)

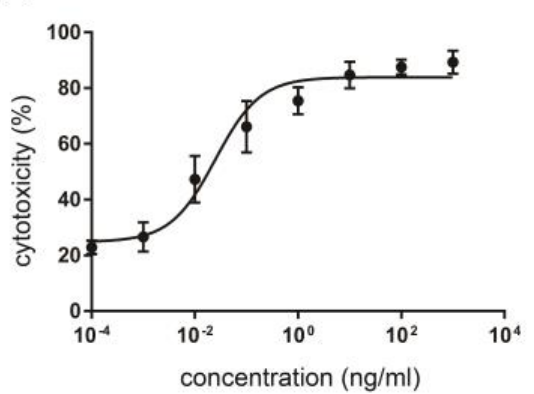

(g)

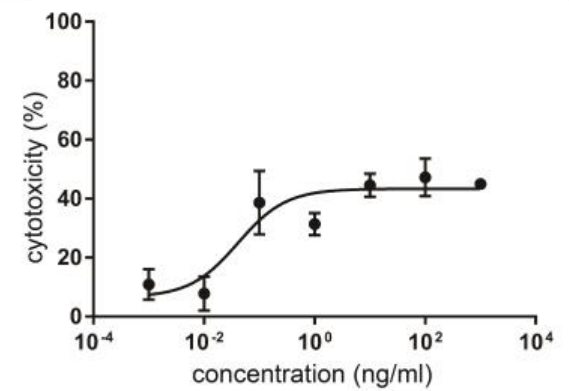

(b)

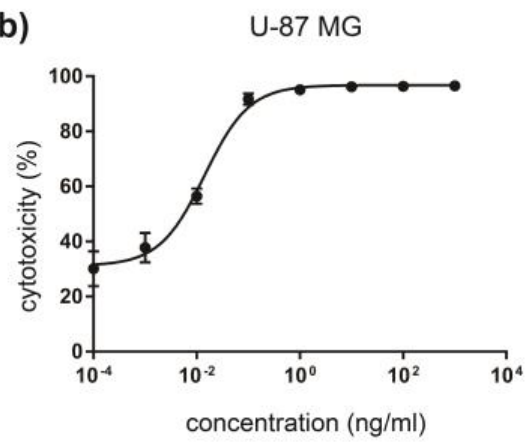

(e)

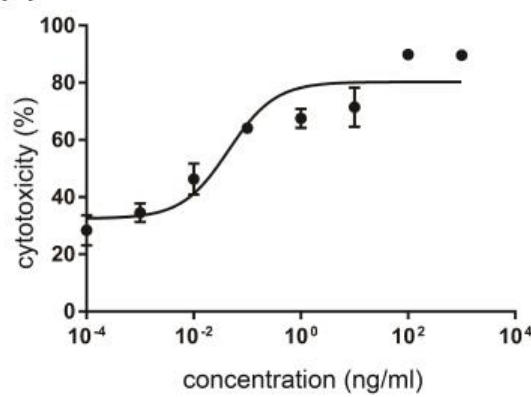

(h)

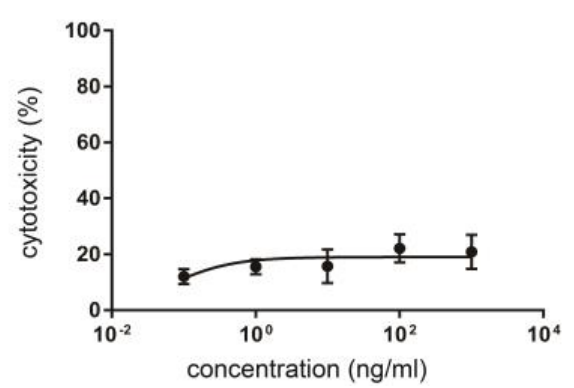

Figure 4. $\alpha \mathrm{B} 7-\mathrm{H} 3 / \mathrm{CD} 3$ mediates T cell cytotoxicity against B7-H3 expressing tumor cells in vitro. (a) Cytotoxic activity of PBMCs in U-87 MG cells mediated by $\alpha$ B7-H3/CD3 or other antibodies was measured by flow cytometry. $n=3, p$-value for mAb mix vs. bsAb: ${ }^{* * *} p<0.001 ;(\mathbf{b}-\mathbf{h}) \alpha \mathrm{B} 7-\mathrm{H} 3 / \mathrm{CD} 3$ demonstrated cytotoxic activity against multiple tumor cell lines (U-87 MG, A498, SKOV3, MDAMB-231, HepG2, K562, and Raji) with various levels of B7-H3 expression, E:T = 10:1. $n=3$, mAb mix, anti-CD3 and anti-B7-H3 mAb mixture; bsAb, $\alpha$ B7-H3/CD3.

Next, we tested the cytotoxic activities of $\alpha$ B7-H3/CD3 against the B7-H3 low-expressing cell lines (K562 and Raji) and multiple cell lines (A498, SKOV3, MDA-MB-231, and HepG2) with various levels of surface B7-H3 expression. Data showed that $\alpha$ B7-H3/CD3 led to minimal cell lysis in B7-H3 low expression tumor cell lines. However, it demonstrated a highly cytotoxic effect resulting in cell death in multiple tumor cell lines with high levels of B7-H3 (Figure $4 b-h$ ). These results suggested that $\alpha$ B7-H3/CD3-mediated cytotoxicity was B7-H3-specific, and its potency depended on B7-H3 expression. 


\section{4. $\alpha B 7-H 3 / C D 3$ Mediates T Cell Activation and Promotes T Cell Proliferation}

The potency of $\alpha \mathrm{B} 7-\mathrm{H} 3 / \mathrm{CD} 3$ to mediate $\mathrm{T}$ cell activation was examined by activation markers (CD69 and cytotoxic granule granzyme B (GrB) expression and cytokine production. Anti-CD3 mAb was used as a positive control. Additionally, since B7-H3 is an immune checkpoint molecule, we wanted to explore whether this anti-B7-H3 mAb could play the role of immune checkpoint blockade. As shown in Figure 5a,b, $\alpha$ B7-H3/CD3 activated CD8+ and CD4+ T cells to a similar extent as anti-CD3 mAb. Anti-B7-H3 mAb had little effect on T cell activation. As shown in Figure 5c, $\alpha B 7-H 3 / C D 3$ mediated significantly more abundant production of IL-2 compared to anti-CD3 mAb or/and anti-B7-H3 $\mathrm{mAb}$. Figure $5 \mathrm{~d}$ showed that the anti-B7-H3 mAb did not induce $\mathrm{T}$ cell proliferation and demonstrated that $\alpha \mathrm{B} 7-\mathrm{H} 3 / \mathrm{CD} 3$ had a stronger effect on induction of both CD8+ (left) and $\mathrm{CD} 4+$ (right) $\mathrm{T}$ cell proliferation compared to anti-CD3 mAb and mAb mix. Additionally, when we replaced U-87 MG with no tumor or Raji, $\alpha$ B7-H3/CD3 did not induce T cell proliferation, which indicated that this effect was associated with the expression of B7-H3 (Figure 5e). These results confirmed that $\alpha \mathrm{B} 7-\mathrm{H} 3 / \mathrm{CD} 3$-mediated activity was accompanied by T cell expansion and activation, and its effect on T cells was B7-H3-dependent. Moreover, $\alpha B 7-H 3 / C D 3$ had a stronger effect on the activation and proliferation of CD8+ T cells than CD4 + T cells.

\section{5. $\alpha B 7-H 3 / C D 3$ Is Potent in Tumor Growth Inhibition In Vivo}

To determine the antitumor efficacy of $\alpha \mathrm{B} 7-\mathrm{H} 3 / \mathrm{CD} 3$ in vivo, the glioblastoma cell line U-87 MG and ovarian carcinoma cell line SKOV3 were used to establish xenograft models in human PBMC-reconstituted mice. U-87 MG/SKOV3 cells $\left(5 \times 10^{6}\right)$ were implanted subcutaneously into the huPBMC-NCG mice. Mice demonstrating tumor development $\left(150 \mathrm{~mm}^{3}\right)$ were treated with doses of $\alpha \mathrm{B} 7-\mathrm{H} 3 / \mathrm{CD} 3$, PBS, or /and anti-B7-H3 mAb (i.p., $2 \times /$ wk $\times 3$ weeks). Tumor volume was evaluated (Figure $6 a, c)$. Figure 6 summarizes the results of these experiments. The inhibitory effect of $\alpha \mathrm{B} 7-\mathrm{H} 3 / \mathrm{CD} 3$ treatment on tumor growth was significant. As shown in Figure 6b, U-87 MG xenografts were completely eliminated after either three or five injections of $5 \mathrm{mg} / \mathrm{kg}$ of $\alpha \mathrm{B} 7-\mathrm{H} 3 / \mathrm{CD} 3$ (i.p.), while the anti-B7-H3 mAb did not suppress tumor growth (Figure S1). In the groups treated with 0.2 and $1 \mathrm{mg} / \mathrm{kg} \alpha \mathrm{B} 7-\mathrm{H} 3 / \mathrm{CD} 3$, complete inhibition of xenografts was observed in most mice ( $5 / 7 \mathrm{of} 0.2 \mathrm{mg} / \mathrm{kg}$ group, $4 / 6$ of $1 \mathrm{mg} / \mathrm{kg}$ group), with a few animals showing small nodules ( $2 / 7$ of $0.2 \mathrm{mg} / \mathrm{kg}$ group, $2 / 6$ of $1 \mathrm{mg} / \mathrm{kg}$ group) (Figure $6 \mathrm{~b}, \mathrm{e})$. In the SKOV3 xenograft model, PBMCs derived from two donors were used to reconstruct the mouse immune system. According to the tumor growth curve, tumors were eradicated in all $\alpha B 7-\mathrm{H} 3 / \mathrm{CD} 3-$ treated mice regardless of the source of PBMCs (Figure 6d,e). Immunofluorescence staining analysis of isolated U-87 MG tumors showed more T cell infiltration in $\alpha B 7-H 3 / C D 3-$ treated mice, indicating that $\alpha \mathrm{B} 7-\mathrm{H} 3 / \mathrm{CD} 3$ effectively recruited and maintained $\mathrm{T}$ cells (Figure 6f). These experiments showed that $\alpha \mathrm{B} 7-\mathrm{H} 3 / \mathrm{CD} 3$ effectively recruited $\mathrm{T}$ cells into tumor sites and mediated antitumor activity in murine xenograft models. 
(a)

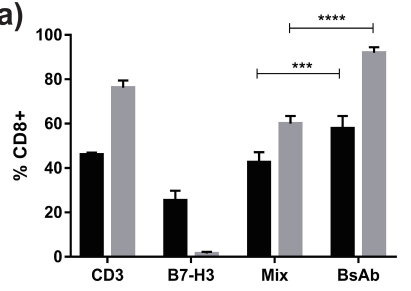

(b)

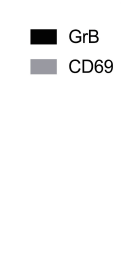

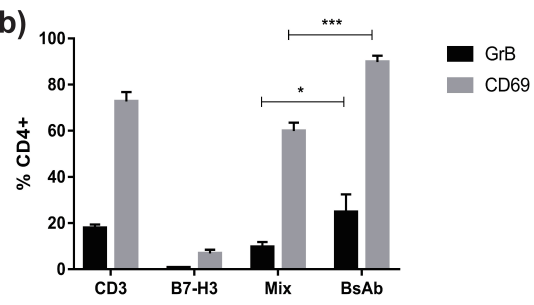

CD8+T

(d) CD3
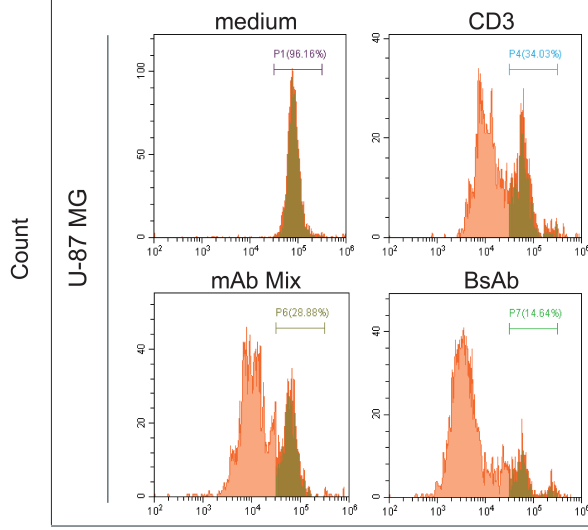

BsAb
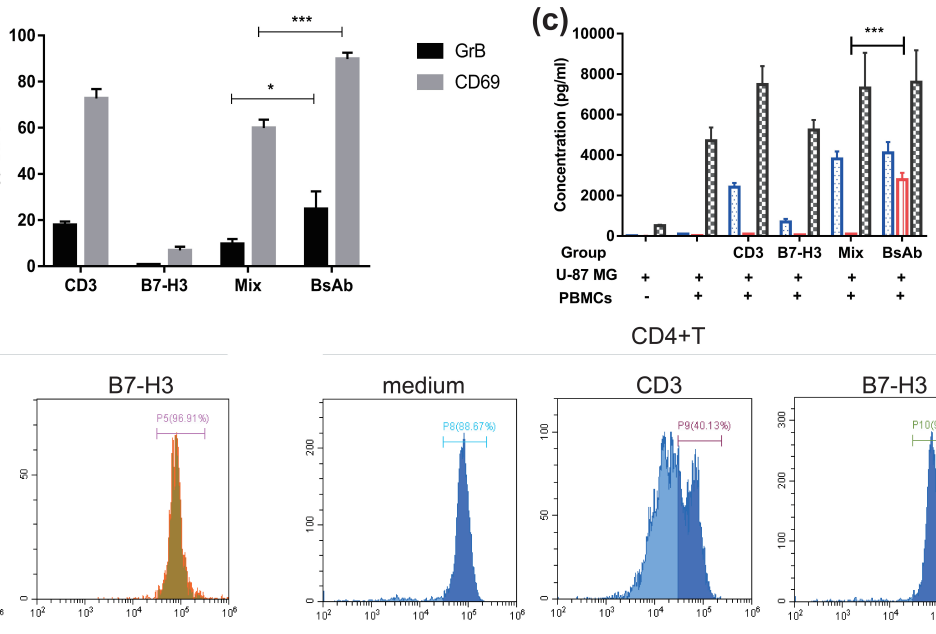

미미 IFN-ץ 때 IL-6 CD4+T CD3

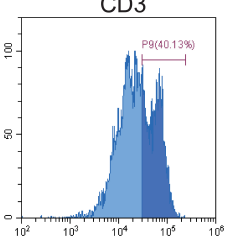
B7-H3

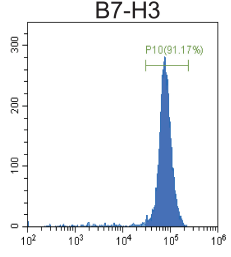

Overlay mAb Mix

BsAb Overlay

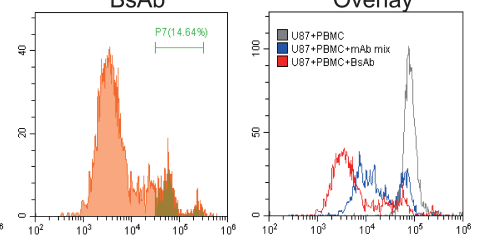

CFSE

(e) CD8+T

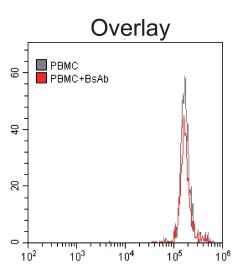

홍

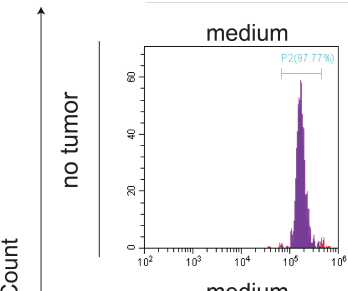
BsAb

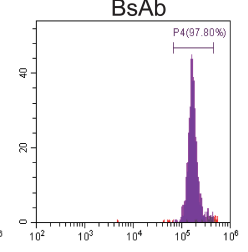

BsAb

Overlay

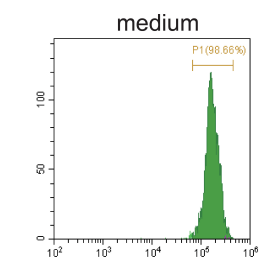

medium
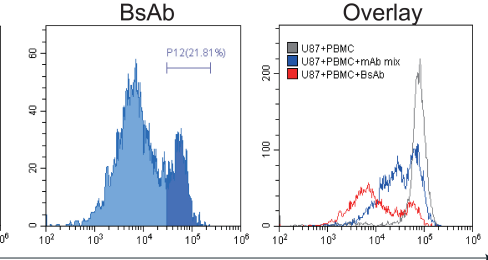

$\mathrm{CD} 4+\mathrm{T}$ BsAb
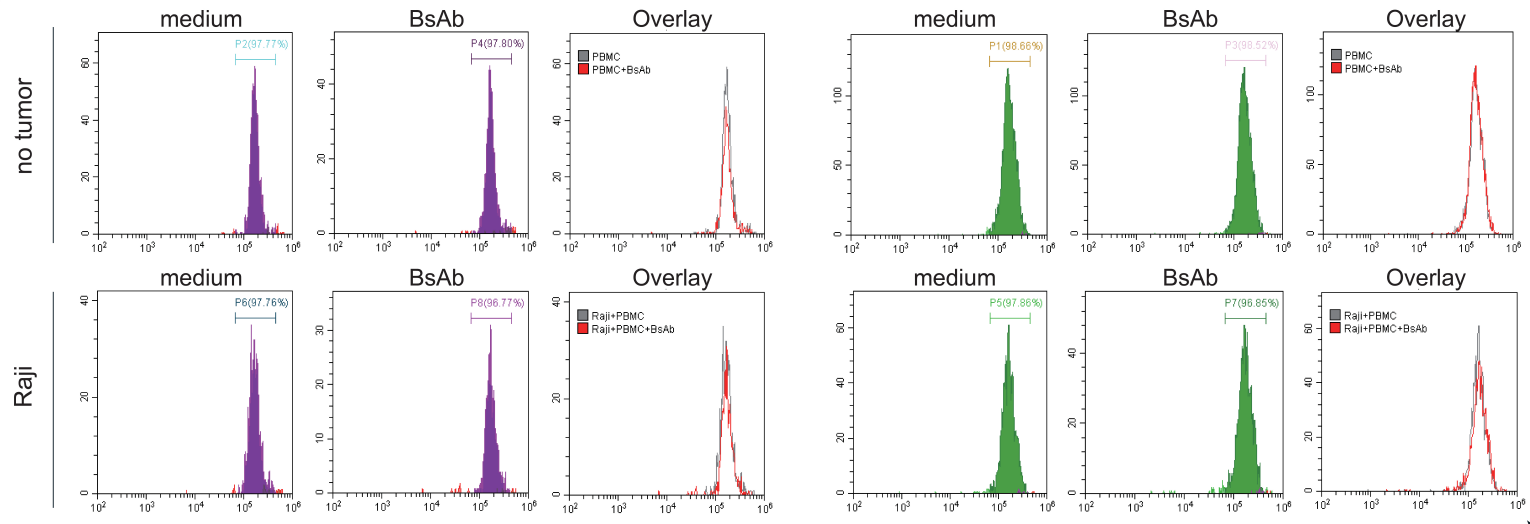

BsAb

Overlay

\section{coses}

Figure 5. $\alpha \mathrm{B} 7-\mathrm{H} 3 / \mathrm{CD} 3$ induces $\mathrm{T}$ cell activation and proliferation in vitro. U-87 MG and PBMCs were co-cultured with indicated antibodies as described in methods. T cell activation markers (CD69 and $\mathrm{GrB}$ ) and $\mathrm{T}$ cell proliferation were analyzed in $\mathrm{CD} 8+$ and $\mathrm{CD} 4+$ subsets by flow cytometry. The profile of cytokines released by PBMCs was quantified using ELISA. (a,b) Percentage of CD69 and GrB-positive cells in CD4+ or CD8+ T cell subsets. $n=3$; (c) Secretion of cytokines by PBMCs induced by the indicated antibodies. $n=3 ;(\mathbf{d}, \mathbf{e}) \mathrm{T}$ cell proliferation was measured using CFSE dilutions. Groups in which U-87 MG was replaced with no tumor or Raji (e). Representative histograms of CFSE-labeled T cells in CD8+ (left) and CD4+ (right) $\mathrm{T}$ cell subsets are shown. CD3, anti-CD3 mAb; B7-H3, anti-B7-H3 mAb; mAb mix, anti-CD3 and anti-B7-H3 mAb mixture; bsAb, $\alpha$ B7-H3/CD3. **** $p<0.0001 ; * * * 0.001 ;{ }^{*} p<0.05$. 
(a)

a) darac

(b)

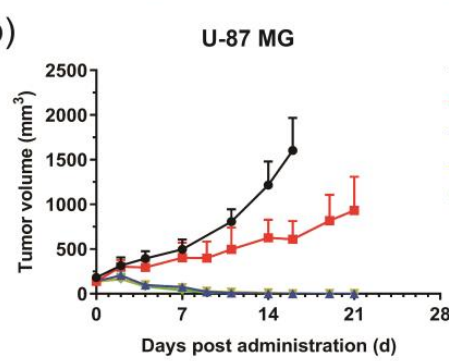

$\begin{array}{ccccccc}\text { day-6 } & \text { day0 } & \text { day3 } & \text { day7 } & \text { day10 } & \text { day14 } & \text { day17 } \\ \text { U-87MG } & \text { Ab } & \text { Ab } & \text { Ab } & \text { Ab } & \text { Ab } & \text { Ab }\end{array}$

s.c. i.p. i.p. i.p. i.p. i.p. ip.

s.c.

$-\frac{100}{20}$

$\rightarrow$ no PBMC,PBS, n=3

- PBMC-01,bsAb(5 mg/kg),n=6

7 PBMC-01.bsab(1 mglkg.n=e

PBMC-01.bsAb(0.2 mg/kg).n=7

(2)

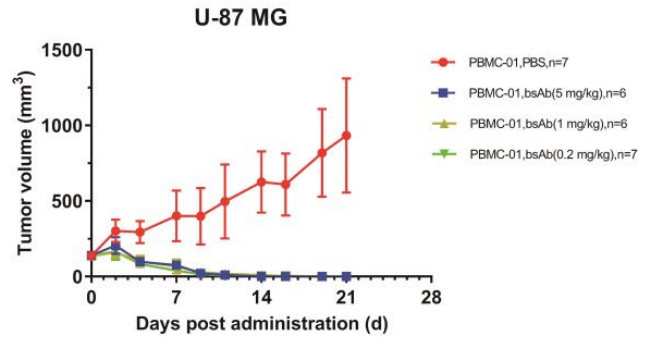

(c)

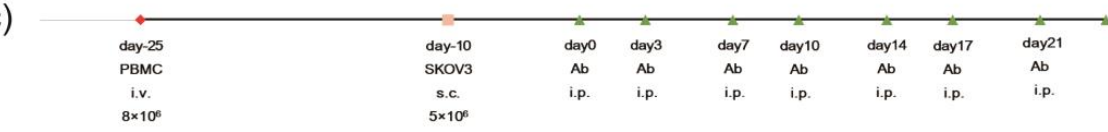

(d)
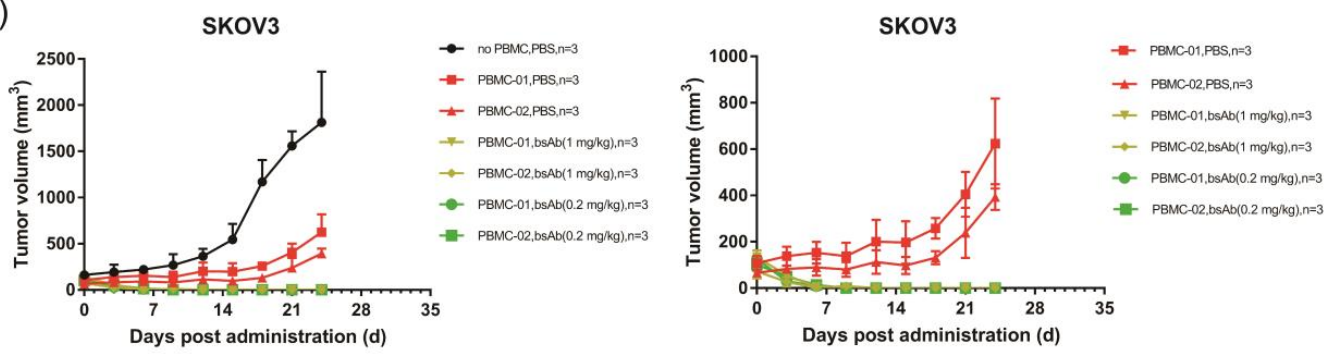

(e)
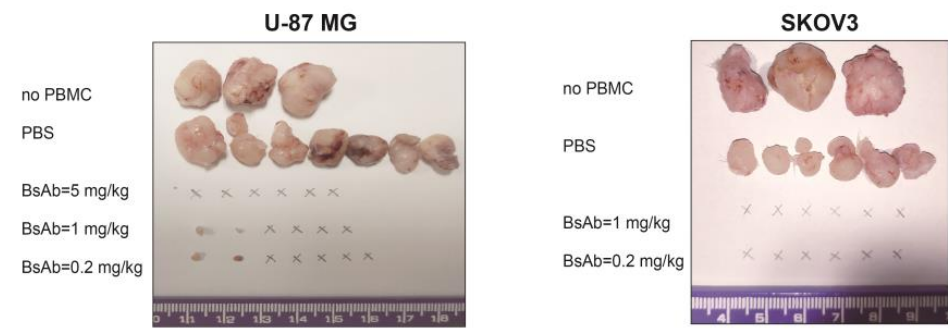

(f)
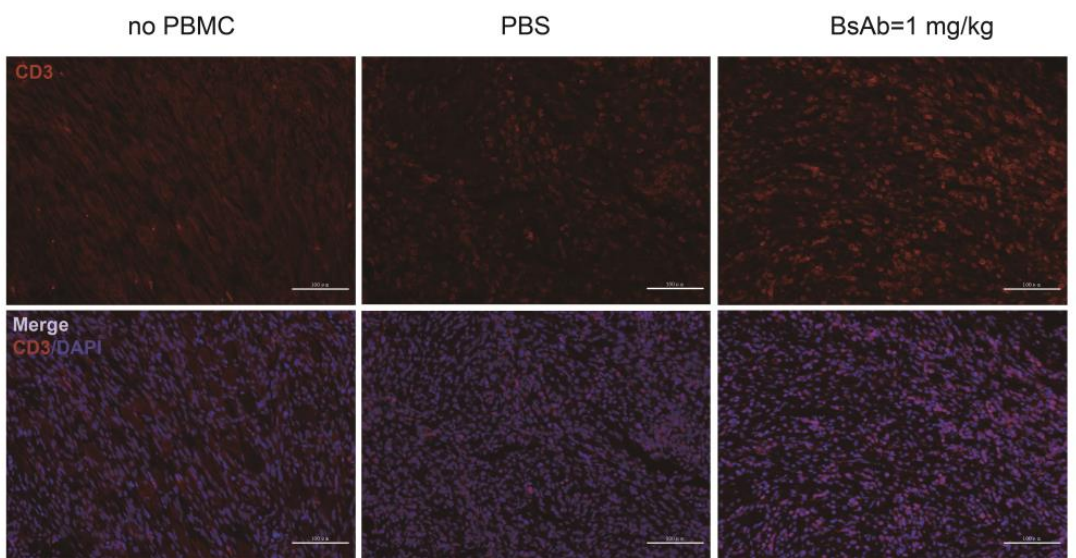

Figure 6. $\alpha$ B7-H3/CD3 inhibits tumor growth in xenograft models using human PBMC-engrafted NCG mouse models. (a,c) Schematic map of the development of U-87 MG (a) and SKOV3 (c) xenograft model. U-87 MG or SKOV3 were subcutaneously implanted into NCG mice engrafted with human PBMCs. Mice were treated with PBS and doses of $\alpha$ B7-H3/CD3 twice a week post tumor development; (b,d) average tumor growth curve of U-87 MG (b) and SKOV3 (d) xenografts for every group. The tumor volume was plotted against the time in days following antibody administration. The number of mice is shown in figures; (e) images of individual xenograft tumors at the end of experiments; (f) immunofluorescence staining analysis of CD3+ T cells (red) in U-87 MG tumors. Scale bar, $100 \mu \mathrm{m}$. bsAb, $\alpha$ B7-H3/CD3. 


\section{Discussion}

Many bsTCEs targeting classical solid tumor antigens, such as HER2, EGFRvIII, PSMA, EpCAM, and CEA, are being explored in clinical practice, and multiple other TAAs are currently pursued in preclinical studies [3]. B7-H3 is a co-inhibitory molecule that overexpressed in various solid tumor tissues and limited in normal tissues, making it an attractive target for bsAb therapy. Here, we described the generation of a novel bsTCE specific to $T$ cells and B7-H3 positive tumors and demonstrated the potential application.

Structure is important for the development of bsAbs. Santich et al. demonstrated that a symmetric dual bivalent bsAb format (IgG-[L]-scFv (" $2+2$ "): anti-CD3 scFv fused to the $\mathrm{C}$ terminus of each antitumor IgG light chain) is more potent than other common bsAb designs (such as BiTE and IgG heterodimer) and IgG-[L]-scFv heterodimers with different combinations of valency and inter-domain spatial configurations [49]. They revealed the beneficial effects of cis-configurations and inter-domain spacing. The asymmetric format developed in our study is similar to one described in their study referred to as " $1+1 C^{\prime \prime}$. " $1+1 C$ " had one antitumor domain replaced and one anti CD3 domain removed from the same side (cis) of " $2+2$ " format. The monovalent format is not good as " $2+2$ " format in terms of anti-tumor efficacy but closely resembles native antibody in size and has inferior $\mathrm{T}$ cell binding. We also generated another format in which anti-CD3 scFv is fused to the $\mathrm{N}$ terminus of the antitumor light chain and demonstrated that the format has superior $\mathrm{T}$ cell binding compared to anti-CD3 scFv fused to $\mathrm{C}$ terminus format (Figure S2). Several studies have shown correlation between CD3 affinity and bsTCE distribution, with higher CD3 affinity shifting bsTCE away from tumor to T-cell-rich tissues [50,51], implying that the format in our study could mitigate on-target off-tumor toxicities.

In addition, asymmetric structure is complicated to manufacture due to the mispairing of heavy and light chains. Here, hetero-dimerization of the heavy chains is achieved by $\mathrm{KIH}$ technology, and there is no light chain pairing as knob $\mathrm{Fc}_{\mathrm{c}}$ is a single fragment. Moreover, the desired end-product can be isolated by designing purification strategies based on sequential affinity chromatography or size differences. Even so, the formation of hole-hole homo-dimers and other impurities reduced the yield of desired end-product. It is necessary to optimize the amino acid sequences or use other strategies to promote the hetero-dimerization of the heavy chains, and the humanization of anti-B7-H3 domain is also essential in subsequent researches.

We confirmed that B7-H3 was highly expressed on surface of most solid tumor cell lines and less expressed on hematoma cell lines. In vitro cytotoxicity analysis of these cell lines showed that the $\alpha \mathrm{B} 7-\mathrm{H} 3 / \mathrm{CD} 3-$ mediated co-engagement of $\mathrm{B} 7-\mathrm{H} 3$ and $\mathrm{CD} 3$ resulted in potent lysis of tumor cells with high B7-H3 expression. These indicated a relationship between expression levels of $\mathrm{B} 7-\mathrm{H} 3$ and $\alpha \mathrm{B} 7-\mathrm{H} 3 / \mathrm{CD} 3$ mediated T cell antitumor activity. Our research also suggested that $\alpha \mathrm{B} 7-\mathrm{H} 3 / \mathrm{CD} 3$ mediated antitumor activity was accompanied by $\mathrm{T}$ cell proliferation and activation and this effect is B7-H3-dependent, and $\alpha \mathrm{B} 7-\mathrm{H} 3 / \mathrm{CD} 3$ has a stronger effect on the activation and proliferation of CD8+ T cells compared to CD4+ T cells. A previous work indicates a role of IL-2 in promoting differentiation of CD8+ effector and memory $\mathrm{T}$ cells [52]. In this study, $\alpha \mathrm{B} 7-\mathrm{H} 3 / \mathrm{CD} 3$ significantly potentiated production of IL-2, which may contribute to enduring the immune responses.

The in vivo tumor growth inhibition activity of antibodies was influenced by the mouse model, the timing of treatment, and the means of administration. Some preclinical studies examined the bsTCEs efficacy using a co-implantation model in which T cells and tumor cell mixtures were implanted into immune-deficient mice. Although this model can shorten the experimental period, it is difficult to accurately evaluate the antitumor efficacy of antibodies because of the lack of tumor development and $\mathrm{T}$ cell infiltration [53]. In addition, PBMC infusion could inhibit the onset of tumor and PBMCs from different donors may have vary influence on tumor establish (Figure 6). Thus, PBMCs derived from patients may be better to establish the humanized immune system and the immunosuppressive microenvironment. In our study, PBMCs from healthy donors were inoculated into immune deficient mice two weeks before tumor implantation to develop a humanized murine model 
of the immune system. $\alpha \mathrm{B} 7-\mathrm{H} 3 / \mathrm{CD} 3$ was administered when the tumor volume reached approximately $150 \mathrm{~mm}^{3}$. We observed the inhibition of established tumors and increase of $\mathrm{T}$ cells infiltration mediated by $\alpha \mathrm{B} 7-\mathrm{H} 3 / \mathrm{CD} 3$. The results demonstrated that $\alpha \mathrm{B} 7-\mathrm{H} 3 / \mathrm{CD} 3$ effectively recruit $\mathrm{T}$ cells into tumor tissue to suppress tumor growth of B7-H3-positive xenograft. We also observed the relief of GVHD symptoms in mice treated with $\alpha \mathrm{B} 7-$ H3/CD3, which was manifested in improvement of mental state, dermatitis symptoms, and liver and kidney damage (Figure S3). This indicated that $\alpha$ B7-H3/CD3 did not bring additional toxicity to mice.

We did not observe antitumor activity in vivo following treatment with anti-B7-H3 $\mathrm{mAb}$ alone, consistently with in vitro results. These results indicated that the ADCC effect mediated by anti-B7-H3 mAb was insufficient to inhibit tumor growth, and this mAb did not play a role as inhibitor of the co-inhibitory molecule B7-H3. Therefore, the mechanism of $\alpha \mathrm{B} 7-\mathrm{H} 3 / \mathrm{CD} 3$ action may only attribute to redirect $\mathrm{T}$ cells to target cells that trigger $\mathrm{T}$ cell activation.

In summary, we describe a novel format for B7-H3-specific, bispecific antibodies. The $\mathrm{bsAb}$ mediated strong in vitro antitumor activity against B7-H3 high-expression tumor cells derived from a wide range of tumor subtypes and may cause less on-target off-tumor toxicities. The $\alpha$ B7-H3/CD3 demonstrated potent suppression of tumor growth in human PBMC-engrafted mice. Our study supports the hypothesis that the novel anti-B7-H3 $\times$ anti-CD3 bsAb is a potential therapeutic strategy for treating B7-H3-positive solid tumors.

Supplementary Materials: The following supporting information can be downloaded at: https: / / www.mdpi.com/article/10.3390/life12020157/s1, Figure S1: Individual tumor growth curve of U-87 MG xenografts of indicated treatments; Figure S2: Comparison of CD3 binding activity of two formats anti-B7-H3/CD3 bsAb; Figure S3: $\alpha$ B7-H3/CD3 elicited no toxicities to liver and kidney.

Author Contributions: Conceptualization, J.F. and Y.F.; methodology, J.F. and Y.F.; validation, T.H. and J.Z.; formal analysis, Y.F.; investigation, Y.F., K.X. and Y.Y.; resources, Y.F., B.L., C.P. and B.W.; data curation, Y.F. and B.L.; writing-original draft preparation, Y.F.; writing-review and editing, J.F., H.G. and X.X.; supervision, J.F. and H.G.; project administration, J.F. and H.G.; funding acquisition, J.F. All authors have read and agreed to the published version of the manuscript.

Funding: This research was funded by the National Natural Science Foundation of China (NSFC82172604) and the National Basic Research Program of China (973 Program) (2015CB553706).

Institutional Review Board Statement: The animal study protocol was approved by the Animal Research Ethics Commit-tee of Tongji University (No. TJLAC-018-032).

Informed Consent Statement: Informed consent was obtained from the PBMCs donors.

Conflicts of Interest: The authors declare no conflict of interest.

\section{References}

1. Kontermann, R.E. Dual targeting strategies with bispecific antibodies. MAbs 2012, 4, 182-197. [CrossRef]

2. Labrijn, A.F.; Janmaat, M.L.; Reichert, J.M.; Parren, P.W.H.I. Bispecific antibodies: A mechanistic review of the pipeline. Nat. Rev. Drug Discov. 2019, 18, 585-608. [CrossRef]

3. Middelburg, J.; Kemper, K.; Engelberts, P.; Labrijn, A.; Schuurman, J.; van Hall, T. Overcoming Challenges for CD3-Bispecific Antibody Therapy in Solid Tumors. Cancers 2021, 13, 287. [CrossRef] [PubMed]

4. Chapoval, A.I.; Ni, J.; Lau, J.S.; Wilcox, R.A.; Flies, D.B.; Liu, D.; Dong, H.; Sica, G.L.; Zhu, G.; Tamada, K.; et al. B7-H3: A costimulatory molecule for T cell activation and IFN-gamma production. Nat. Immunol. 2001, 2, 269-274. [CrossRef]

5. Sun, X.; Vale, M.; Leung, E.; Kanwar, J.R.; Gupta, R.; Krissansen, G.W. Mouse B7-H3 induces antitumor immunity. Gene Ther. 2003, 10, 1728-1734. [CrossRef] [PubMed]

6. Luo, L.; Chapoval, A.I.; Flies, D.B.; Zhu, G.; Hirano, F.; Wang, S.; Lau, J.S.; Dong, H.; Tamada, K.; Flies, A.; et al. B7-H3 enhances tumor immunity in vivo by costimulating rapid clonal expansion of antigen-specific CD8+ cytolytic T cells. J. Immunol. 2004, 173, 5445-5450. [CrossRef] [PubMed]

7. Lupu, C.; Eisenbach, C.; Lupu, A.; Kuefner, M.; Hoyler, B.; Stremmel, W.; Encke, J. Adenoviral B7-H3 therapy induces tumor specific immune responses and reduces secondary metastasis in a murine model of colon cancer. Oncol. Rep. 2007, 18, 745-748. [CrossRef] 
8. Loos, M.; Hedderich, D.M.; Ottenhausen, M.; Giese, N.A.; Laschinger, M.; Esposito, I.; Kleeff, J.; Friess, H. Expression of the costimulatory molecule B7-H3 is associated with prolonged survival in human pancreatic cancer. BMC Cancer $2009,9,463$. [CrossRef]

9. Ling, V.; Wu, P.W.; Spaulding, V.; Kieleczawa, J.; Luxenberg, D.; Carreno, B.M.; Collins, M. Duplication of primate and rodent B7-H3 immunoglobulin V- and C-like domains: Divergent history of functional redundancy and exon loss. Genomics 2003, 82, 365-377. [CrossRef]

10. Suh, W.-K.; Gajewska, B.U.; Okada, H.; Gronski, M.; Bertram, E.M.; Dawicki, W.; Duncan, G.S.; Bukczynski, J.; Plyte, S.; Elia, A.J.; et al. The B7 family member B7-H3 preferentially down-regulates T helper type 1-mediated immune responses. Nat. Immunol. 2003, 4, 899-906. [CrossRef]

11. Leitner, J.; Klauser, C.; Pickl, W.F.; Stöckl, J.; Majdic, O.; Bardet, A.F.; Kreil, D.P.; Dong, C.; Yamazaki, T.; Zlabinger, G.; et al. B7-H3 is a potent inhibitor of human T-cell activation: No evidence for B7-H3 and TREML2 interaction. Eur. J. Immunol. 2009, 39, 1754-1764. [CrossRef] [PubMed]

12. Jin, Y.; Zhang, P.; Li, J.; Zhao, J.; Liu, C.; Yang, F.; Yang, N.; Gao, A.; Lin, W.; Ma, X.; et al. B7-H3 in combination with regulatory $\mathrm{T}$ cell is associated with tumor progression in primary human non-small cell lung cancer. Int. J. Clin. Exp. Pathol. 2015, 8, 13987-13995.

13. Chen, J.-T.; Chen, C.-H.; Ku, K.-L.; Hsiao, M.; Chiang, C.-P.; Hsu, T.-L.; Chen, M.-H.; Wong, C.-H. Glycoprotein B7-H3 overexpression and aberrant glycosylation in oral cancer and immune response. Proc. Natl. Acad. Sci. USA 2015, 112, 13057-13062. [CrossRef]

14. Sun, Y.; Wang, Y.; Zhao, J.; Gu, M.; Giscombe, R.; Lefvert, A.K.; Wang, X. B7-H3 and B7-H4 expression in non-small-cell lung cancer. Lung Cancer 2006, 53, 143-151. [CrossRef]

15. Roth, T.J.; Sheinin, Y.; Lohse, C.M.; Kuntz, S.M.; Frigola, X.; Inman, B.; Krambeck, A.E.; McKenney, M.E.; Karnes, R.J.; Blute, M.L.; et al. B7-H3 ligand expression by prostate cancer: A novel marker of prognosis and potential target for therapy. Cancer Res. 2007, 67, 7893-7900. [CrossRef]

16. Zang, X.; Thompson, R.H.; Al-Ahmadie, H.A.; Serio, A.M.; Reuter, V.E.; Eastham, J.A.; Scardino, P.T.; Sharma, P.; Allison, J.P. B7-H3 and B7x are highly expressed in human prostate cancer and associated with disease spread and poor outcome. Proc. Natl. Acad. Sci. USA 2007, 104, 19458-19463. [CrossRef]

17. Yuan, H.; Wei, X.; Zhang, G.; Li, C.; Zhang, X.; Hou, J. B7-H3 over expression in prostate cancer promotes tumor cell progression. J. Urol. 2011, 186, 1093-1099. [CrossRef]

18. Chen, Y.; Zhao, H.; Zhu, D.; Zhi, Q.; He, S.; Kuang, Y.; Li, D.; Zhang, Z.; Song, S.; Zhang, L.; et al. The coexpression and clinical significance of costimulatory molecules B7-H1, B7-H3, and B7-H4 in human pancreatic cancer. Onco. Targets Ther. 2014, 7, 1465-1472. [CrossRef]

19. Zang, X.; Sullivan, P.S.; Soslow, R.A.; Waitz, R.; Reuter, V.E.; Wilton, A.; Thaler, H.T.; Arul, M.; Slovin, S.F.; Wei, J.; et al. Tumor associated endothelial expression of B7-H3 predicts survival in ovarian carcinomas. Mod. Pathol. 2010, 23, 1104-1112. [CrossRef] [PubMed]

20. Brunner, A.; Hinterholzer, S.; Riss, P.; Heinze, G.; Brustmann, H. Immunoexpression of B7-H3 in endometrial cancer: Relation to tumor T-cell infiltration and prognosis. Gynecol. Oncol. 2012, 124, 105-111. [CrossRef] [PubMed]

21. Ingebrigtsen, V.A.; Boye, K.; Tekle, C.; Nesland, J.M.; Flatmark, K.; Fodstad, Ø. B7-H3 expression in colorectal cancer: Nuclear localization strongly predicts poor outcome in colon cancer. Int. J. Cancer 2012, 131, 2528-2536. [CrossRef] [PubMed]

22. Sun, T.-W.; Gao, Q.; Qiu, S.-J.; Zhou, J.; Wang, X.-Y.; Yi, Y.; Shi, J.-Y.; Xu, Y.-F.; Shi, Y.-H.; Song, K.; et al. B7-H3 is expressed in human hepatocellular carcinoma and is associated with tumor aggressiveness and postoperative recurrence. Cancer Immunol. Immunother. 2012, 61, 2171-2182. [CrossRef] [PubMed]

23. Liu, C.; Liu, J.; Wang, J.; Liu, Y.; Zhang, F.; Lin, W.; Gao, A.; Sun, M.; Wang, Y.; Sun, Y. B7-H3 expression in ductal and lobular breast cancer and its association with IL-10. Mol. Med. Rep. 2013, 7, 134-138. [CrossRef] [PubMed]

24. Qin, X.; Zhang, H.; Ye, D.; Dai, B.; Zhu, Y.; Shi, G. B7-H3 is a new cancer-specific endothelial marker in clear cell renal cell carcinoma. Onco. Targets Ther. 2013, 6, 1667-1673. [CrossRef]

25. Hu, J.; Jiang, C.; Zheng, M.; Guo, Y.; Tang, X.; Ren, J.; Lu, D.; Yu, L.; Gan, W.; Liu, S.; et al. Overexpression of B7-H3 as an opportunity for targeted therapy in head and neck cancers. Am. J. Transl. Res. 2019, 11, 5183-5196.

26. Seaman, S.; Zhu, Z.; Saha, S.; Zhang, X.M.; Yang, M.Y.; Hilton, M.B.; Morris, K.; Szot, C.; Morris, H.; Swing, D.A.; et al. Eradication of Tumors through Simultaneous Ablation of CD276/B7-H3-Positive Tumor Cells and Tumor Vasculature. Cancer Cell 2017, 31, 501-515.e8. [CrossRef] [PubMed]

27. Feng, R.; Chen, Y.; Liu, Y.; Zhou, Q.; Zhang, W. The role of B7-H3 in tumors and its potential in clinical application. Int. Immunopharmacol. 2021, 101 Pt B, 108153. [CrossRef]

28. Flem-Karlsen, K.; Fodstad, Ø.; Nunes-Xavier, C.E. B7-H3 Immune Checkpoint Protein in Human Cancer. Curr. Med. Chem. 2020, 27, 4062-4086. [CrossRef]

29. Nagase-Zembutsu, A.; Hirotani, K.; Yamato, M.; Yamaguchi, J.; Takata, T.; Yoshida, M.; Fukuchi, K.; Yazawa, M.; Takahashi, S.; Agatsuma, T. Development of DS-5573a: A novel afucosylated mAb directed at B7-H3 with potent antitumor activity. Cancer Sci. 2016, 107, 674-681. [CrossRef] 
30. Ahmed, M.; Cheng, M.; Zhao, Q.; Goldgur, Y.; Cheal, S.M.; Guo, H.-F.; Larson, S.M.; Cheung, N.-K.V. Humanized Affinitymatured Monoclonal Antibody 8H9 Has Potent Antitumor Activity and Binds to FG Loop of Tumor Antigen B7-H3. J. Biol. Chem. 2015, 290, 30018-30029. [CrossRef]

31. Loo, D.; Alderson, R.F.; Chen, F.Z.; Huang, L.; Zhang, W.; Gorlatov, S.; Burke, S.; Ciccarone, V.; Li, H.; Yang, Y.; et al. Development of an Fc-enhanced anti-B7-H3 monoclonal antibody with potent antitumor activity. Clin. Cancer Res. 2012, 18, 3834-3845. [CrossRef]

32. Nehama, D.; Di Ianni, N.; Musio, S.; Du, H.; Patané, M.; Pollo, B.; Finocchiaro, G.; Park, J.J.; Dunn, D.E.; Edwards, D.S.; et al. B7-H3-redirected chimeric antigen receptor T cells target glioblastoma and neurospheres. EBioMedicine 2019, 47, 33-43. [CrossRef] [PubMed]

33. Yang, S.; Wei, W.; Zhao, Q. B7-H3, a checkpoint molecule, as a target for cancer immunotherapy. Int. J. Biol. Sci. 2020, 16, 1767-1773. [CrossRef]

34. Moore, P.; Chichili, G.; Alderson, R.; Li, H.; Brown, J.; Huang, L.; Ciccarone, V.; Burke, S.; Gorlatov, S.; Chen, F.; et al. Data from MacroGenics' Preclinical Studies of MGD009 Presented at Keystone Symposia's Antibodies as Drugs (X2) Conference. 2016. Available online: https:/ /ir.macrogenics.com/events.cfm (accessed on 21 March 2021).

35. Ma, J.; Ma, P.; Zhao, C.; Xue, X.; Han, H.; Liu, C.; Tao, H.; Xiu, W.; Cai, J.; Zhang, M. B7-H3 as a promising target for cytotoxicity T cell in human cancer therapy. Oncotarget 2016, 7, 29480-29491. [CrossRef]

36. Ma, W.; Ma, J.; Ma, P.; Lei, T.; Zhao, M.; Zhang, M. Targeting immunotherapy for bladder cancer using anti-CD3 $\times$ B7-H3 bispecific antibody. Cancer Med. 2018, 7, 5167-5177. [CrossRef] [PubMed]

37. Sun, X.; Yu, Y.; Ma, L.; Xue, X.; Gao, Z.; Ma, J.; Zhang, M. T cell cytotoxicity toward hematologic malignancy via B7-H3 targeting Investig. New Drugs 2020, 38, 722-732. [CrossRef] [PubMed]

38. Ma, J.; Shang, T.; Ma, P.; Sun, X.; Zhao, J.; Sun, X.; Zhang, M. Bispecific anti-CD3 x anti-B7-H3 antibody mediates T cell cytotoxic ability to human melanoma in vitro and in vivo. Investig. New Drugs 2019, 37, 1036-1043. [CrossRef]

39. Li, H.; Huang, C.; Zhang, Z.; Feng, Y.; Wang, Z.; Tang, X.; Zhong, K.; Hu, Y.; Guo, G.; Zhou, L.; et al. MEK Inhibitor Augments Antitumor Activity of B7-H3-Redirected Bispecific Antibody. Front. Oncol. 2020, 10, 1527. [CrossRef]

40. Zheng, M.; Yu, L.; Hu, J.; Zhang, Z.; Wang, H.; Lu, D.; Tang, X.; Huang, J.; Zhong, K.; Wang, Z.; et al. Efficacy of B7-H3-Redirected BiTE and CAR-T Immunotherapies Against Extranodal Nasal Natural Killer/T Cell Lymphoma. Transl. Oncol. 2020, 13, 100770. [CrossRef]

41. Ridgway, J.B.; Presta, L.G.; Carter, P. ‘Knobs-into-holes' engineering of antibody CH3 domains for heavy chain heterodimerization Protein Eng. 1996, 9, 617-621. [CrossRef]

42. Atwell, S.; Ridgway, J.B.; Wells, J.A.; Carter, P. Stable heterodimers from remodeling the domain interface of a homodimer using a phage display library. J. Mol. Biol. 1997, 270, 26-35. [CrossRef]

43. Liu, R.; Oldham, R.; Teal, E.; Beers, S.; Cragg, M. Fc-Engineering for Modulated Effector Functions-Improving Antibodies for Cancer Treatment. Antibodies 2020, 9, 64. [CrossRef]

44. Lobner, E.; Traxlmayr, M.; Obinger, C.; Hasenhindl, C. Engineered IgG1-Fc-one fragment to bind them all. Immunol. Rev. 2016, 270, 113-131. [CrossRef] [PubMed]

45. Bruserud, O.; Frostad, S.; Foss, B. In vitro culture of acute myelogenous leukemia blasts: A comparison of four different culture media. J. Hematother. 1999, 8, 63-73. [CrossRef] [PubMed]

46. Gillissen, M.; Yasuda, E.; de Jong, G.; Levie, S.; Go, D.; Spits, H.; van Helden, P.; Hazenberg, M. The modified FACS calcein AM retention assay: A high throughput flow cytometer based method to measure cytotoxicity. J. Immunol. Methods 2016, 434, 16-23. [CrossRef] [PubMed]

47. Quah, B.J.; Parish, C.R. New and improved methods for measuring lymphocyte proliferation in vitro and in vivo using CFSE-like fluorescent dyes. J. Immunol. Methods 2012, 379, 1-14. [CrossRef] [PubMed]

48. Iizuka, A.; Nonomura, C.; Ashizawa, T.; Kondou, R.; Ohshima, K.; Sugino, T.; Mitsuya, K.; Hayashi, N.; Nakasu, Y.; Maruyama, K.; et al. A T-cell-engaging B7-H4/CD3-bispecific Fab-scFv Antibody Targets Human Breast Cancer. Clin. Cancer Res. 2019, 25, 2925-2934. [CrossRef] [PubMed]

49. Santich, B.H.; Park, J.A.; Tran, H.; Guo, H.-F.; Huse, M.; Cheung, N.-K.V. Interdomain spacing and spatial configuration drive the potency of IgG-[L]-scFv T cell bispecific antibodies. Sci. Transl. Med. 2020, 12, eaax1315. [CrossRef]

50. Mandikian, D.; Takahashi, N.; Lo, A.A.; Li, J.; Eastham-Anderson, J.; Slaga, D.; Ho, J.; Hristopoulos, M.; Clark, R.; Totpal, K.; et al. Relative Target Affinities of T-Cell-Dependent Bispecific Antibodies Determine Biodistribution in a Solid Tumor Mouse Model Mol. Cancer Ther. 2018, 17, 776-785. [CrossRef]

51. Bortoletto, N.; Scotet, E.; Myamoto, Y.; D'Oro, U.; Lanzavecchia, A. Optimizing anti-CD3 affinity for effective T cell targeting against tumor cells. Eur. J. Immunol. 2002, 32, 3102-3107. [CrossRef]

52. Mitchell, D.M.; Ravkov, E.V.; Williams, M.A. Distinct roles for IL-2 and IL-15 in the differentiation and survival of CD8+ effector and memory T cells. J. Immunol. 2010, 184, 6719-6730. [CrossRef] [PubMed]

53. Fisher, T.S.; Hooper, A.T.; Lucas, J.; Clark, T.H.; Rohner, A.K.; Peano, B.; Elliott, M.W.; Tsaparikos, K.; Wang, H.; Golas, J.; et al. A CD3-bispecific molecule targeting P-cadherin demonstrates T cell-mediated regression of established solid tumors in mice. Cancer Immunol. Immunother. 2018, 67, 247-259. [CrossRef] [PubMed] 